\title{
GAMBARAN AKUMULASI PLAK PADA ANAK-ANAK USIA 9-12 TAHUN DI KELURAHAN MALALAYANG II KECAMATAN MALALAYANG KOTA MANADO
}

\author{
Youla Karamoy ${ }^{1}$, Jeanne Zavera Adam² \\ Jurusan Keperawatan Gigi Poltekkes Kemenkes Manado \\ Email : karamoyyoula@gmail.com,
}

\begin{abstract}
ABSTRAK
Plak gigi merupakan deposit lunak yang melekat pada permukaan gigi terdiri atas mikroorganisme yang berkembang biak dalam suatu matriks intraseluler jika seorang melalaikan kebersihan gigi dan mulutnya. Plak gigi tidak dapat hanya dibersihkan dengan cara kumur ataupun semprotan air dan hanya dibersihkan secara sempurna dengan cara mekanis. Tujuan : untuk mengetahui gambaran Akumulasi plak pada anak-anak umur 9-12 tahun di Kelurahan Malalayang II Kecamatan Malalayang Kota Manado. Metode : Jenis penelitian dengan menggunakan metode deskriptif, populasi dalam penelitian ini adalah anakanak umur 9-12 tahun di Kelurahan Malalayang II Kecamatan Malalayang Kota, yang berjumlah 303 orang. Teknik pengambilan sampel dengan cara purposive sampling. Jumlah sampel 101 responden. Pengumpulan data dengan pemeriksaan indeks plak, kemudian ditabulasi dan disajikan dalam bentuk tabel distribusi frekuensi dan grafik. Hasil penelitian : Distribusi karakteristik responden berdasarkan umur menunjukkan bahwa responden paling banyak berumur 10 tahun yaitu 34 orang $(33.7 \%)$ dan paling sedikit berumur 12 tahun yaitu 17 orang (16.8). Distribusi karakteristik responden berdasarkan jenis kelamin menunjukkan bahwa responden paling banyak adalah laki-laki yaitu 54 orang (53.5\%) sedangkan perempuan 47 orang (46.5\%). Akumulasi plak pada anak usia 9-12 tahun di Kelurahan Malalayang II Kecamatan Malalayang Kota Manado yang dinilai berdasarkan indeks plak menunjukkan bahwa kriteria sangat baik tidak ada (0\%), kriteria baik $11.9 \%$, kriteria sedang $36.6 \%$ dan kriteria buruk 51.5\%. Kesimpulan : Sebagian besar 51.5\% dari 101 anak-anak yang berumur 9-12 tahun di Kelurahan Malalayang II mempunyai indeks plak dalam kategori buruk dan tidak ada yang berkategori baik.
\end{abstract}

\section{Kata Kunci : Plak, Anak-anak 9-12 Tahun}

\section{ABSTRACT}

Dental plaque is a soft deposit attached to the tooth surface consisting of microorganisms that multiply in an intracellular matrix if a person neglects the cleanliness of his teeth and mouth. Dental plaque cannot only be cleaned by gargling or spraying water and only cleaned thoroughly by mechanical means. Objective: to find out the description of plaque accumulation in children aged 9-12 years in Malalayang II Village, Malalayang District, Manado City. Methods: This type of research uses descriptive methods, the population in this study were children aged 9-12 years in Malalayang II Village, Malalayang Kota District, totaling 303 people. The sampling technique is by purposive sampling. The number of samples was 101 respondents. Data collection by plaque index checking, then tabulated and presented in the form of frequency distribution tables and graphs. Results: The distribution of respondents' characteristics by age showed that most respondents were 10 years old, 34 people (33.7\%) and at least 12 years old, 17 people (16.8). Distribution of respondent characteristics based on gender showed that the most respondents were male, 54 people (53.5\%) while women 47 people (46.5\%). Plaque accumulation in children aged 9-12 years in Malalayang II Village, Malalayang Subdistrict, Manado City which was assessed based on 
plaque index showed that there were very good criteria (0\%), good criteria $11.9 \%$, moderate criteria $36.6 \%$ and bad criteria $51.5 \%$. Conclusion: Most of the 51.5\% of 101 children aged 9-12 years in Malalayang II Village had a plaque index in the bad category and none were categorized as good.

Keywords: Plaque, Children 9-12 years

\section{PENDAHULUAN}

Kesehatan gigi dan mulut anak sangat penting menjadi perhatian bagi orang tua karena akan mempengaruhi kesehatan anak secara keseluruhan. Penyebab utama terjadinya penyakit gigi dan mulut adalah terjadinya penumpukan plak pada permukaan gigi. Plak gigi merupakan deposit lunak yang melekat erat pada permukaan gigi terdiri atas mikroorganisme yang berkembangbiak dalam satu matriks intraseluler jika seorang melalaikan kebersihan gigi dan mulutnya. Plak gigi sebagian besar terdiri atas dan berbagi macam mikroorganisme yang berkembangbiak dalam satu matriks intraseluler yang terdiri atas polisakharida ekstraseluler dan protein saliva. Plak merupakan faktor utama penyebab terjadinya penyakit gigi dan mulut terutama karies dan penyakit periodontal. ${ }^{1}$

Penyakit gigi dan mulut masih banyak diderita oleh masyarakat Indonesia baik oleh anak-anak maupun usia dewasa. Berdasarkan hasil Riskesdas 2013 menunjukkan sebesar $25,9 \%$ penduduk Indonesia mempunyai masalah gigi dan mulut dan meningkat pada tahun 2018 menjadi 57,6 \%. Di Provinsi Sulawesi Utara penduduk yang bermasalah kesehatan gigi dan mulut tahun 2013 sebanyak 21,6\% dan tahun 2018 menjadi sekitar $65 \%$.,3 $^{2,3}$

Berdasarkan hasil survei awal yang diambil secara acak pada 20 orang anak yang tinggal di Kelurahan Malalayang II didapatkan nilai rata-rata indeks plak 3,2 termasuk kriteria sedang. Sementara data tentang kesehatan gigi tentang akumulasi plak pada anak-anak secara keseluruhan di Kelurahan Malalayang II belum diketahui.
Padahal plak merupakan faktor utama pencetus masalah kesehatan gigi. Penelitian ini bertujuan untuk mengetahui gambaran akumulasi plak pada anak-anak 9-12 tahun di Kelurahan Malalayang II Kecamatan Malalayang Kota Manado.

\section{METODE}

Metode penelitian yang digunakan yaitu metode deskriptif, yang memungkinkan peneliti untuk membuat deskripsi, gambaran, secara sistematis, faktual dan akurat mengenai fakta-fakta yang diselidiki. Penelitian dilakukan pada bulan September 2018 di Kelurahan Malalayang II Kecamatan Malalayang Kota Manado. ${ }^{4}$

Variabel pada penelitian ini bersifat monovariabel yaitu akumulasi plak pada anak usia 9-12 tahun di Kelurahan Malalayang II Kecamatan Malalayang Kota Manado. Instrumen dalam penelitian ini alat diagnostik set dan format pemeriksaan plak. Populasi dalam penelitian ini yaitu seluruh anak-anak yang berumur 9-12 tahun di Kelurahan Malalayang II Kecamatan Malalayang Kota Manado, yang berjumlah 303 orang. Teknik pengambilan sampel dengan cara purposive sampling yang berjumlah 101 responden dengan kriteria inklusi; bersedia menjadi subjek penelitian dan menandatangani inform consent yang disetujui orang tua.

\section{HASIL}

1. Distribusi karakteristik responden penelitian dapat dilihat pada tabel 1 
Tabel 1. Karakteristik Responden

\begin{tabular}{llcr}
\hline \multicolumn{2}{c}{$\begin{array}{c}\text { Karaktaeristik } \\
\text { Responden }\end{array}$} & Frekuensi & \% \\
\hline Umur & 9 Tahun & 32 & 31.7 \\
& 10 Tahun & 34 & 33.7 \\
& 11 Tahun & 18 & 17.8 \\
& 12 Tahun & 17 & 16.8 \\
Jenis & Total & $\mathbf{1 0 1}$ & $\mathbf{1 0 0 . 0}$ \\
Kelamin & Laki-laki & 54 & 53.5 \\
& Perempuan & 47 & 46.5 \\
& Total & $\mathbf{1 0 1}$ & $\mathbf{1 0 0 . 0}$ \\
\hline
\end{tabular}

Distribusi karakteristik responden berdasarkan umur menunjukkan bahwa responden paling banyak berumur 10 tahun yaitu 34 orang $(33.7 \%)$ dan paling sedikit berumur 12 tahun yaitu 17 orang (16.8). Distribusi karakteristik responden berdasarkan jenis kelamin menunjukkan bahwa responden paling banyak adalah laki-laki yaitu 54 orang $(53.5 \%)$ sedangkan perempuan 47 orang (46.5\%).

2. Distribusi kriteria indeks plak pada anak-anak yang berumur 9-12 tahun di Kelurahan Malalayang II Kecamatan Malalayang Kota Manado

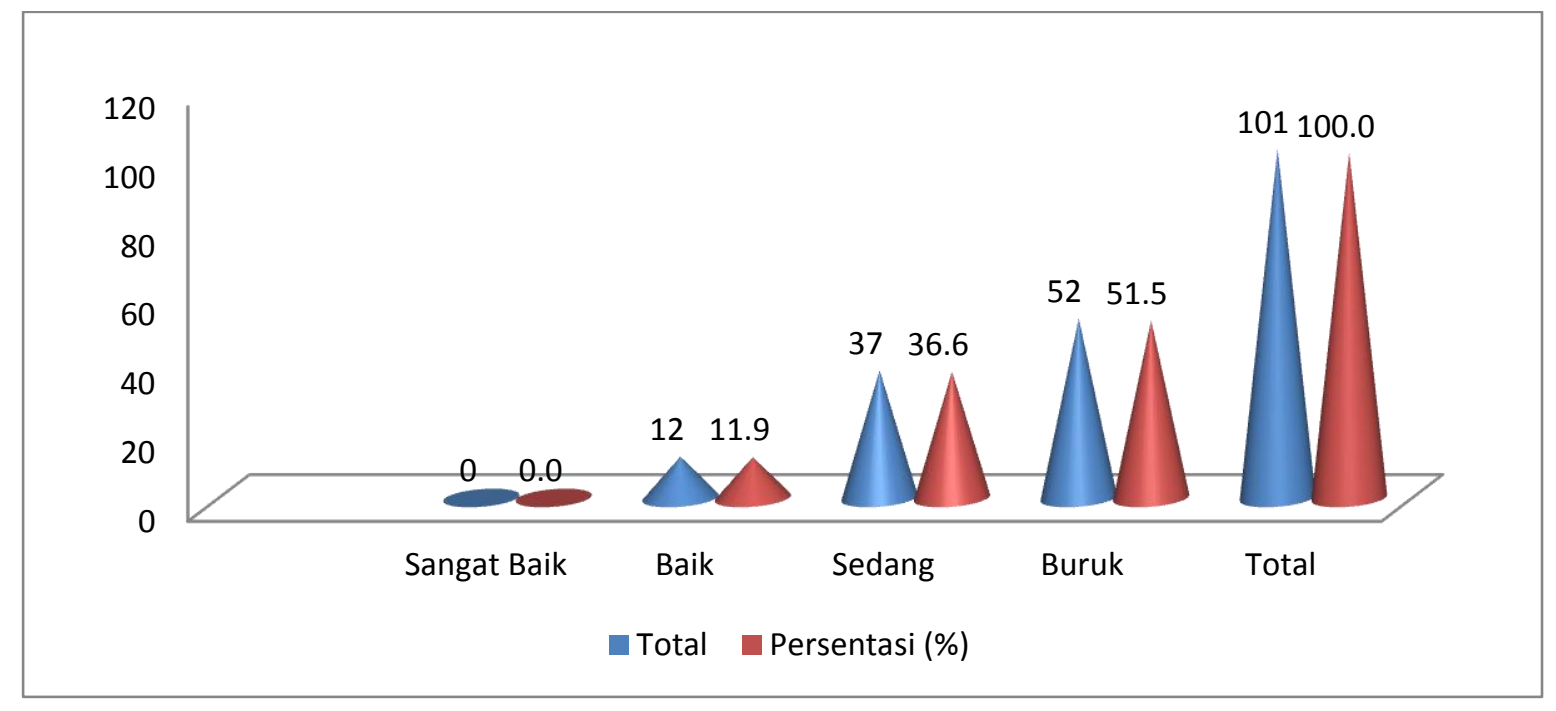

Gambar 1. Distribusi kriteria plak pada anak usia 9-12 tahun di Kelurahan Malalayang II Kecamatan Malalayang Kota Manado

Pada gambar 1 dapat dilihat bahwa akumulasi plak pada anak usia 9-12 tahun di Kelurahan Malalayang II Kecamatan Malalayang Kota Manado yang dinilai berdasarkan indeks plak menunjukkan bahwa tidak ada responden yang memiliki

\section{PEMBAHASAN}

Masalah kesehatan gigi dan mulut masih merupakan hal yang perlu mendapat perhatian serius dari masyarakat Indonesia mulai dari anak-anak sampai dengan orang dewasa. Kebersihan gigi dan mulut yang baik berdampak pada kesehatan gigi dan kriteria indeks plak sangat baik (0\%), sedangkan untuk kriteria baik hanya $11.9 \%$ responden, kriteria sedang $36.6 \%$ dan paling banyak yaitu kriteria buruk $51.5 \%$.

mulut, sebaliknya kebersihan mulut yang kurang terjaga dapat menyebabkan berbagai macam penyakit pada rongga mulut. $^{5}$

Hasil penelitian ini menunjukkan akumulasi plak pada anak usia 9-12 tahun di Kelurahan Malalayang II Kecamatan Malalayang Kota Manado yang dinilai 
berdasarkan indeks plak diketahui bahwa dari 101 responden yang diperiksa tidak ada responden yang memiliki kriteria indeks plak sangat baik $(0 \%)$, sedangkan untuk kriteria baik ada $11.9 \%$ responden, kriteria sedang $36.6 \%$ dan paling banyak yaitu kriteria buruk 51.5\%. Hal ini menunjukkan status kebersihan gigi dan mulut yang dinilai menggunakan indeks plak pada responden masih tergolong kurang, karena sebagian besar responden termasuk dalam kriteria buruk. Berdasarkan wawancara hal ini dikarenakan anak-anak masih sering lupa menyikat gigi jika tidak diingatkan orang tua. Selain itu anak-anak sering makan makanan yang manis dan mudah melekat yang tersedia di kompleks sekolahan dan disekitar tempat tinggal.

Plak memiliki peranan yang besar pada timbulnya karies dan penyakit periodontal, maka akumulasi plak perlu dicegah dengan pelaksanaan plak kontrol. Kontrol plak adalah pengambilan bakteri plak dan pencegahan menumpuknya pada gigi dan permukaan gingiva yang berdekatan. $^{6}$

Usaha pertama yang dapat dilakukan untuk mencegah dan mengontrol pembentukan plak gigi, meliputi mengatur pola makanan, ${ }^{7}$ Tindakan pertama yang dapat dilakukan untuk mencegah atau mengontrol pembentukan plak adalah dengan membatasi makanan yang banyak mengandung karbohidrat terutama sukrosa. Berdasarkan bukti-bukti bahwa karbohidrat merupakan bahan utama dalam pembentukan matriks plak, selain sebagai sumber energi untuk bakteri dalam membentuk plak. Makanan yang lunak dan mudah menempel pada gigi sebaiknya sedapat mungkin dihindari.

Usaha yang kedua yaitu tindakan secara kimiawi terhadap bakteri dan terhadap polisakarida ekstraseluler. Berdasarkan sifat-sifat mikrobiologis plak, telah dilakukan berbagai usaha untuk mencegah bakteri berkolonisasi di atas permukaan gigi membentuk plak. Beberapa penelitian yang telah dilakukan antara lain adalah dengan menggunakan antibiotik dansenyawa-senyawa antibakteri selain antibiotik. Efektivitas antibakteri oral harus memiliki spektrum yang luas terhadap aktivitas antibakteri, tetapi juga harus tidak mengganggu mikroba oral normal. Keberhasilan agen antibakteri tergantung tidak hanya pada daya antibakteri tetapi juga pada kandungan substantifnya. Karena kemampuannya terikat pada permukaan oral dan konsentrasi bio-aktif, agen antibakteri substantif tetap aktif dalam rongga mulut untuk jangka waktu lama. Plak yang tertinggal setelah menyikat dapat menyerap agen antibakteri yag terdapat pada obat kumur. ${ }^{8}$

Usaha yang ketiga yaitu : tindakan secara mekanis berupa pembersihan rongga mulut dan gigi dari semua sisa makanan, bakteri beserta hasil-hasil metabolismenya. Tindakan secara mekanis adalah tindakan membersihkan gigi dan mulut dari sisa makanan dan debris yang bertujuan untuk mencegah terjadinya penyakit pada jaringan keras maupun jaringan lunak. Pada tindakan secara mekanis untuk menghilangkan plak, lazim digunakan alat fisioterapi oral adalah sikat gigi merupakan salah satu alat fisioterapi oral yang digunakan secara luas untuk membersihkan gigi dan mulut. ${ }^{7,8}$

Kontrol plak dengan menyikat gigi sangat penting untuk kebersihan rongga mulut. Menjaga kebersihan rongga mulut harus dimulai pada pagi hari, baik sebelum maupun setelah sarapan. Menyikat gigi sebelum sarapan akan mengurangi potensi erosi mekanis pada permukaan gigi yang telah demineralisasi. Dilanjutkan dengan menjaga kebersihan rongga mulut yang dilakukan pada malam hari sebelum tidur. Ketika tidur, aliran saliva akan berkurang sehingga efek buffer akan berkurang, karena itu semua plak harus dibersihkan. Jika diperlukan, pengontrolan plak lebih jauh, dapat menggunakan benang gigi (dental floss) atau alat-alat interdental lainnya. ${ }^{9}$ 
Perawatan gigi sangat penting untuk dimulai sejak usia dini yaitu sejak anakanak. Membersihkan gigi dan mulut sejak masa anak-anak tentunya akan membuat anak terbiasa dan pada saat inilah kebiasaan menjaga kesehatan gigi dan mulut sangat penting. ${ }^{10}$

\section{KESIMPULAN}

Berdasarkan hasil penelitian dapat disimpulkan bahwa sebagian besar atau $51.5 \%$ dari 101 anak-anak yang berumur 9-12 tahun di Kelurahan Malalayang II mempunyai indeks plak dalam kategori buruk dan tidak ada yang berkategori baik.

\section{SARAN}

Setelah membahas hasil penelitian ini, maka yang menjadi saran adalah :

1. Bagi anak-anak : agar dapat menjaga kesehatan gigi dan mulutnya yaitu dengan mengontrol makanan dengan mengurangi makanan yang manis dan melekat, rajinlah menyikat gigi minimal 2 kali sehari dan berkumur jika selesai makan dan memeriksakan gigi setiap 6 bulan sekali ke sarana pelayanan kesehatan gigi.

2. Bagi pemerintah : agar memfasilitasi penyediaan wastafel di lingkungan sekolah dan himbauan bagi pihak sekolah-sekolah agar tidak menjual makanan yang manis dan melekat terutama di kantin sekolah.

\section{DAFTAR PUSTAKA}

1. Putri, H. M, Herijulianti, E (\&) Nurjanah. N. (2011) Ilmu Pencegahan Penyakit Jaringan Keras dan Jaringan Pendukung Gigi. EGC. Jakarta.

2. Kemenkes,RI (2013). Riset Kesehatan Dasar. Badan Penelitian dan Pengembangan. Jakarta.

3. Kemenkes,RI (2018). Riset Kesehatan Dasar. Badan Penelitian dan Pengembangan Kemenkes RI. Jakarta.

4. Soekidjo, Notoadmodjo. (2010). Metodologi Penelitian Kesehatan. Rineka Cipta. Jakarta.

5. Sriyono, N.W. (2005). Pengantar Ilmu Kedokteran Gigi Pencegahan. Medika Fakultas Kedokteran UGM. Yogyakarta.

6. Bahar, Armasastra (2011). Paradigma Baru Pencegahan Karies Gigi. Lembaga Penerbit Fakultas Ekonomi UI. Jakarta.

7. Kidd, E.A.M dan Bechal-J, S (1991). Dasar-Dasar Karies Gigi Penyakit Dan Penangulangan. EGC. Jakarta.

8. Tarigan Rasinta. 2012, Karies Gigi, Hipocrates. Jakarta.

9. Ghofur, A (2012). Buku Pintar Kesehatan Gigi dan Mulut. Buku Pintar. Yogyakarta.

10. Budiharto. 2010. Ilmu Perilaku Kesehatan dan Pendidikan Kesehatan Gigi. EGC. Jakarta. 